\title{
ONKOLOGIJA JUČER, DANAS, SUTRA
}

\author{
Inga Marijanović ${ }^{1,2}$, Teo Buhovac ${ }^{1,2}$ \\ ${ }^{1}$ Klinika za onkologiju, Sveučilišne kliničke bolnice Mostar \\ ${ }^{2}$ Fakultet zdravstvenih studija Sveučilišta u Mostaru \\ Rad je primljen 11.4.2017. Rad je recenziran 13.4.2017. Rad je prihvaćen 21.4.2017.
}

\section{SAŽETAK}

U ovom trenutku onkologija je jedna od najdinamičnijih grana medicine. U tijeku su brojna klinička istraživanja vezana za razumijevanje biologije tumorskih stanica čija saznanja se kasnije koriste $\mathrm{u}$ „dizajniranju” protutumorskih lijekova. Napretkom ostalih grana medicine omogućen je i napredak onkologije. U prošlosti je kirurgija bila jedini modaliet liječenja karcinoma. Kasnije su primjenom hormonske terapije, radioterapije te kemoterapije značajno poboljšani rezultati liječenja. Osim navedenih terapijskih modaliteta, standard u liječenju karcinoma danas predstavljaju i nove vrste lijekova poput inhibitora angiogeneze, monoklonskih protutijela, tirozin-kinaznih inhibitora i mnogih drugih. Napredak u onkologiji je doveo do toga da su danas pojedine vrste karcinoma izlječive što ranije nije bio slučaj. Obzirom na dosadašnje trendove, u budućnosti se očekuje povećanje broja oboljelih od karcinoma. U ovom trenutku u svijetu su brojna klinička istraživanja lijekova koji su pokazali protutumorski potencijal u pretkliničkim istraživanjima. Cilj onkologije u budućnosti je što je moguće više individualizirati liječenje karcinoma te karcinom pretvoriti od smrtonosne u kroničnu bolest, a cilj ovog rada je prikazati mogućnosti i razvoj onkologije i njene sve veće mogućnosti u liječenju onkoloških bolesnika.

Ključne riječi: onkologija, karcinom, onkološki modaliteti, budućnost onkologije

Osoba za razmjenu informacija

Dr.sc. Inga Marijanović, dr.med.

E mail: inga.marijanovic71@gmail.com

\section{UVOD}

Možemo reći da smo svjedoci onkološke revolucije? Čitav niz novih načina liječenja tumora potvrđuje istu, a sve utemeljeno na razumijevanju biološkog načina funkcioniranja stanica, odnosno genskog aparata organizma. Sve ovo znači za osobe oboljele od raka bolje sutra, ali i značajno bolje danas.

Onkologija je jedna od najdinamičnijih grana medicine. Razvoj i napredak onkologije usko je povezan i s razvojem i napretkom drugih grana medicine kao što su kirurgija, patologija, radiologija, farmakologija, biologija itd. Zahvaljujući sve boljim metodama dijagnostike i screeninga, te novim opcijama liječenja proteklih godina je značajno poboljšano preživljenje pacijenata s karcinomom. Zbog sve većeg broja terapijskih opcija i modaliteta liječenja, danas se liječenje malignih bolesti zasniva na multidisciplinarnom pristupu. Multidisciplinarni timovi koje čine specijalisti različitih medicinskih grana koje su uključene u dijagnostiku i liječenje određene vrste karcinoma su standard kod donošenja odluka vezanih za onkološke pacijente.

\section{PROŠLOST}

Najstariji opis karcinoma potječe iz Egipta, a tumori na kostima otkriveni su na ljudskim ostacima starim preko 3000 godina. Kirurško liječenje je prvi i dugo vremena jedini korišteni modalitet liječenja karcinoma. Godine 1761. Giovanni Morgagni je bio prvi koji je radio autopsije da bi povezao pacijentovu bolest sa patološkim nalazom nakon smrti što predstavlja početak „Znanstvene” onkologije. Otkrivanjem anestezije u 19. stoljeću omogućen je razvoj kirurgije općenito, pa tako i kirurškog liječenja karcinoma Krajem 19. stoljeća kirurg sir George Thomas 
Beatson je objavio svoje opažanje da se uklanjanjem jajnika (ooforektomijom) u bolesnica s uznapredovalim rakom dojke može postići regresija bolesti. Njegovim otkrićem da razvoj raka dojke može biti povezan $s$ hormonima započinje razvoj homonske terapije u liječenju i prevenciji raka dojke (1). Oko 50 godina kasnije američki urolog Charles Huggins otkriva povezanost raka prostate i muških hormona čime udara temelje primjeni hormonske terapije $\mathrm{u}$ liječenju pacijenata s rakom prostate(2). Početkom 20. stoljeća započinje i primjena zračenja u dijagnostici i terapiji tumora. Kemoterapija podrazumijeva primjenu lijekova koji uništavaju tumorske stanice. Prvi citostatik je bio dušikov plikavac koji se 1943. godine počeo primjenjivati u liječenju limfoma(3). Time započinje era kemoterapije u liječenju zloćudnih tumora. Otkriveno je i da je kombinacija citostatika potencijalno učinkovitija od monoterapije.

\section{SADAŠNJOST}

Današnja onkologija sa sve većim uspjehom kombinira ranije spomenute terapijske modalitete (kirurgija, radioterapija, kemoterapija, hormonska terapija) u liječenju karcinoma. Uz te modalitete liječenja danas i imunoterapija predstavlja standard liječenja određenih vrsta karcinoma. Krajem 90 -ih godina prošlog stoljeća započinje primjena monoklonskih protutijela rituksimaba i trastuzumaba u liječenju malignih bolesti $(4,5)$. Takozvane ciljane terapije koje inhibiraju angiogenezu ili blokiraju signale rasta tumora su također danas u primjeni u liječenju sve većeg broja pacijenata s malignim bolestima (6.) Bevacizumab je prvi lijek koji inhibira stvaranje krvnih žila u tumoru i zaustavlja angiogenezu, a koristi se kao dio terapije u mnogih vrsta tumora (debeloga crijeva, dojke, pluća, bubrega...) (7).

Onkologija je zahvaljujući razvoju molekularne biologije prije desetak godina krenula putem individualiziranja terapije. Riječ je o novokoncipiranim genskim potpisima. Amsterdamski potpis čine 70 gena iz kojih se može iščitati niz parametara koji determiniraju zloćudnost tumora, ali i učinkovitost određene terapije (8). Bit će to novi korak u individualizaciji dijagnostike, čime će se učinkovitost liječenja multiplicirati, a uštedjet će se velik novac jer se neće trošiti lijekovi koji pojedincu ne koriste. I bit će senzacija kada se otkriju takvi prvi, ciljani specifični testovi koji će na razini pojedinca predodrediti učinkovitost "pametnih" lijekova. Iz godine u godinu, zahvaljujući ekstremnom napretku molekularne onkologije, tumore upoznajemo sve više, te dizajniramo lijekove $u$ odnosu na njihove primijećene slabe točke. Otkiveno je oko 650 tumoru pridruženih onkogena (gena koji su uključeni u rast tumora), a sada nam je poznato i da rast i razvoj tumora vrlo često počiva na blokiranju tumor-supresorskih gena (geni koji sprečavaju rast tumora), pa se danas radi na lijekovima koji uspostavljaju aktivnost tumor-supresorskih gena ili pak, inhibiraju onkogene.

Liječenje oboljelih od raka definitivno se promijenilo. Prije deset godina smrtnost od, raka dojke, pet godina nakon otkrića bolesti, iznosila je 80 posto (15). Danas, zahvaljujući napretku znanosti, pet godina nakon postavljanja dijagnoze raka dojke preživljenje iznosi 90 posto (15). Dobre rezultate u liječenju tumora, osim kod raka dojke, liječnici postižu i u liječenju tumora testisa, koji je gotovo 100 posto izlječiv. Bilježi se veliki napredak i kod liječenja raka debelog crijeva, potom raka grlića maternice, raka prostate, raka pluća, raka bubrega i hematoloških tumora. Sve te bolesti se ne liječe samo jednim lijekom. Prošlo je vrijeme u kojem se vjerovalo kako će jedan lijek izliječiti tumor. Taj zastarjeli koncept liječenja danas je zamijenjen pristupom koji je sličan liječenju HIV-a i AIDS-a: pacijentima se daje kombinirana terapija, zapravo "koktel lijekova" koji pored medikamenata u klasičnom smislu riječi uključuje i različite druge terapije liječenja raka, a u liječenju danas direktno pomažu i nove dijagnostičke metode. Jedna od prekretnica u istraživanju tumora bila je upravo spoznaja da su tumori puno kompliciraniji i dinamičniji nego što se vjerovalo prije 20 godina. Individualizacija liječenja glavna je i najjača poruka Drugi smjer u suvremenoj onkologiji sve je veći broj radova i kliničkih ispitivanja lijekova koji djeluju na molekularnoj razini, na razini stanice, što je novi važan korak prema individualiziranoj terapiji zloćudnih bolesti.

Napredak u onkologiji se može prikazati na primjeru melanoma. Maligni je melanom u 
metastatskoj fazi ranije bio apsolutno neizlječiv, no danas imamo dva nova kvalitetna lijeka - ipilimumab i vemurafenib (9). Ranije je kemoterapija smatrana standardom u liječenju metastatskog melanoma, no samo 10 do 20 posto bolesnika je imalo pozitivan odgovor na navedeno liječenje. Stoga je i preživljenje takvih pacijenata bilo relativno malo tek 10 do 20 posto oboljelih preživjelo bi godinu do dvije. Vemurafenib je dizajniran zahvaljujući značajnom napretku u razumijevanju glasničkih putova unutar tumora. Otkriveno je kako je 40 do 70 posto melanoma povezano s takozvanom BRAF V600E mutacijom, te je pronađen način za utvrđivanje da li je melanom povezan s tom mutacijom (9). Ipilimumab je lijek koji se temelji na revolucionarnom otkriću mehanizma kojim se sprečava blokada imunološkog sustava organizma u njegovoj borbi protiv raka. To je monoklonsko protutijelo koje pobuđuje imunološku aktivnost protiv stanica melanoma, a istraživanja su pokazala da bolesnici koji se liječe tom vrstom terapije imaju dvostruko veći odgovor na liječenje i preživljenje u usporedbi s klasičnom kemoterapijom (10). Daljnja istraživanja ukazuju na još bolje rezultate u liječenju metastatskog melanoma imunoterapijom novim lijekovima (nivolumab, pembrolizumab) koji će se još istraživati u budućnosti (11). Ti lijekovi su već danas u svijetu standard u liječenju metastatskog melanoma. Drugi primjer koji jasno oslikava napredak u onkologiji su gastrointestinalni tumori, tzv. GIST, od kojega se prije desetak godina umiralo u prosjeku za 12 mjeseci, a danas je to samo kronična bolest (12). Rak dojke je najčešća maligna bolest u žena. Prije 20 godina prosječno preživljenje žena s metastatskim rakom dojke bilo je godinu dana, danas su to tri pa i pet godina, što je izvanredno za metastatsku bolest. Žene u kojih se rak dojke otkrije u ranoj fazi (bez metastaza) u 92 posto slučajeva imaju petogodišnje preživljenje, dok je prije 20 godina petogodišnje preživljenje imalo samo 40 posto žena (13).

Posebno značenje u napretku liječenja HER2 pozitivnog raka dojke je otkriće monoklonskog protutijela trastuzumaba.

\section{BUDUĆNOST}

Rak više nije smrtna presuda i moramo se odmaknuti od te stigme. Od ukupnoga broja oboljelih od zloćudnih bolesti više od polovine ih bude izliječeno i ti ljudi prožive svoj normalan životni vijek. Zahvaljujući pametnim lijekovima, individuliziranoj terapiji, kao i ranom otkrivanju, u svijetu je danas oko 25 milijuna ljudi koji su preživjeli rak, čak pet puta više nego prije tridesetak godina (14). S otkrićem novih lijekova broj preživjelih u budućnosti će uvelike porasti.

Različiti pokazatelji upućuju na to da će broj oboljelih od karcinoma se povećavati s vremenom. Tako neke projekcije govore da se do 2030. očekuje da će broj novooboljelih od karcinoma iznositi oko 21 milijun godišnje što je u najvećoj mjeri posljedica starenja stanovništva i povećanja svjetske populacije. To predstavlja novi izazov za onkologiju koja je u ovom trenutku jedna od najdinamičnijih grana medicine. Pretpostavlja se da će se nastaviti trendovi takozvane personalizirane medicine, tj. da će otkriće novih genetskih i molekularnih markera i testova biti vodič za planiranje onkološkog liječenja. Također, za očekivati je da će brojne nove spoznaje o signalima i metaboličkim putevima uključenim u karcinogenezu rezultirati novim terapijskim ciljevima. Stoga se očekuje sve veći broj novih lijekova u primjeni u skorijoj budućnosti za liječenje malignih bolesti.

\section{ZAKLJUČAK}

Promatrajući razvoj onkologije kroz povijest vidljiv je napredak u liječenju malignih bolesti. Može se reći da je taj napredak sve intenzivniji, pogotovo u zadnjih 20 godina. Od ranih početaka liječenja zloćudnih bolesti kirurgijom do današnjeg liječenja koje uključuje kirurgiju, radioterapiju, hormonsku terapiju, imunoterapiju itd., značajno su poboljšani rezultati liječenja malignih bolesti. U budućnosti uz nove spoznaje i nove terapijske opcije očekuje se da će ti rezultati biti još i bolji. Cilj je postići da karcinom više ne bude smrtonosna već kronična bolest. 


\section{LITERATURA}

1. Beatson G. On the treatment of inoperable cases of carcinoma of the mamma: suggestions for a new method of treatment with illustrative cases. Lancet 1896; 2:104-7.

2. Huggins $C$, Hodges CV. Studies on prostatic cancer. I. The effects of castration, of estrogen and of androgen injection on serum phosphatase in metastatic carcinoma of the prostate. Cancer Res 1941; 1:293-7.

3. DeVita Jr. et al. A History of Cancer Chemotherapy Cancer Research 2008;68:21

4. Li, Y., Williams ME, J. B. Cousar et al. Rituximab/ CD20 complexes are shaved from Z138 mantle cell lymphoma cells in intravenous and subcutaneous SCID mouse models. J. Immunol. 2007; 179:4263-4271.

5. Hudis, C. A.Trastuzumab: mechanism of action and use in clinical practice. N. Engl. J. Med. 2007; 357:39-51.

6. Galizia, G., D. Lieto, De Vita F. Cetuximab, a chimeric human mouse anti-epidermal growth factor receptor monoclonal antibody, in the treatment of human colorectal cancer. Oncogene 2007; 26:3654-3660.

7. Hurwitz $\mathrm{H}$ Kabbinavar F et al Bevacizumab plus Irinotecan, Fluorouracil, and Leucovorin for Metastatic Colorectal Cancer N Eng J Med 2004; 350:2335-2342
8. Buyse M, Loi S, van't Veer L, et al.: Validation and clinical utility of a 70-gene prognostic signature for women with node-negative breast cancer. J Natl Cancer Inst 2006; 98(17):1183-92

9. Davies H, Bignell GR, Cox C, Stephens P, Edkins $\mathrm{S}$, Clegg S, et al. Mutations of the BRAF gene in human cancer. Nature. 2002; 417:949-954.

10.Finn L, Markovic SN, Joseph RW. Therapy for metastatic melanoma: the past, present, and future. BMC Med. 2012;10:23

11.Larkin J., Chiarion-Sileni V., Gonzalez R., Grob J.J., Cowey C.L., Lao C.D., Schadendorf D., Dummer R., Smylie M., Rutkowski P. Combined nivolumab and ipilimumab or monotherapy in untreated melanoma. N. Engl. J. Med. 2015; 373:23-34.

12.Kitamura Yukihiko. Gastrointestinal stromal tumors: past, present, and future. J Gastroenterol. 2008; 43:499-508.

13.Slamon DJ, Godolphin W, Jones LA et al. Studies of the HER-2/neu proto-oncogene in human breast and ovarian cancer. Science 1989; 244:707-12

14.Jamal A, Bray F et al. Global Cancer Statistics CA Cancer J Clin 2011; 61:69-90

15.Breast Cancer Survival Rates and StatisticsAmerican Cancer Society https://www.cancer. org/cancer/breast-cancer/ 


\title{
ONCOLOGY YESTERDAY, TODAY, TOMORROW
}

\author{
Inga Marijanović, ${ }^{1,2}$, Teo Buhovac ${ }^{1,2}$ \\ ${ }^{1}$ Oncology Clinic, University Clinical Hospital Mostar, \\ ${ }^{2}$ Faculty of Health Studies, University of Mostar
}

\begin{abstract}
At this point oncology is one of the most dynamic branches of medicine. Numerous clinical studies are underway to understand tumor cell biology, whose knowledge is later used in "designing" of antitumor drugs. Advancement of other branches of medicine enabled the advancement of oncology. In the past, surgery was the only modality of cancer treatment. Later, the use of hormone therapy, radiation therapy and chemotherapy significantly improved treatment results. In addition to the aforementioned therapeutic modalities, the standard for cancer treatment today also represents new types of drugs such as angiogenesis inhibitors, monoclonal antibodies, tyrosine kinase inhibitors and many others. Advancement of oncology has led to the fact that today certain types of cancer are treatable which was not the case before. Given the current trends, increase in the number of people affected by cancer is expected in the future. Today, there are numerous clinical trials in the world that have shown the anti-tumor potential in preclinical studies. In the future, the aim of oncology is to individualize the treatment of cancer as much as possible, and transform cancer from a fatal to a chronic disease, and the aim of this paper is to present the possibilities and development of oncology and its ever-increasing potential in the treatment of cancer patients.
\end{abstract}

Key words: oncology, cancer, oncology modalities, future of oncology

\section{Correspondence:}

Inga Marijanović, $\mathrm{MD}, \mathrm{PhD}$

E mail: inga.marijanovic71@gmail.com 